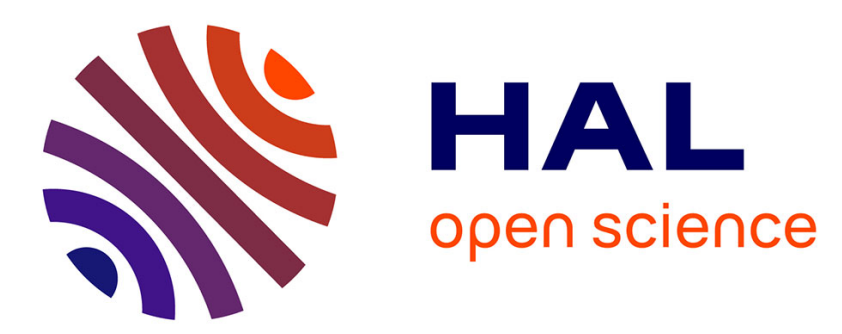

\title{
Diachronous exhumation of HP-LT metamorphic rocks from southwestern Alps: evidence from fission-track analysis
}

Stéphane Schwartz, Jean Marc Lardeaux, Pierre Tricart, Stéphane Guillot, Erika Labrin

\section{To cite this version:}

Stéphane Schwartz, Jean Marc Lardeaux, Pierre Tricart, Stéphane Guillot, Erika Labrin. Diachronous exhumation of HP-LT metamorphic rocks from southwestern Alps: evidence from fission-track analysis. Terra Nova, 2007, pp.1-8. 10.1111/j.1365-3121.2006.00728.x . hal-00137461

\section{HAL Id: hal-00137461 https://hal.science/hal-00137461}

Submitted on 20 Mar 2007

HAL is a multi-disciplinary open access archive for the deposit and dissemination of scientific research documents, whether they are published or not. The documents may come from teaching and research institutions in France or abroad, or from public or private research centers.
L'archive ouverte pluridisciplinaire HAL, est destinée au dépôt et à la diffusion de documents scientifiques de niveau recherche, publiés ou non, émanant des établissements d'enseignement et de recherche français ou étrangers, des laboratoires publics ou privés. 
Diachronous exhumation of HP-LT metamorphic rocks from southwestern Alps: evidence from fission-track analysis

S. Schwartz (1), J.M. Lardeaux (2), P. Tricart (3), S. Guillot (3), and E. Labrin (3)

(1) LIRIGM, Université Joseph Fourier, BP 53, 38041 Grenoble Cedex, France.

(2) UMR Géosciences Azur, Université Nice Sophia-Antipolis, Nice, France.

(3) LGCA-CNRS, Université Joseph Fourier, BP 53, 38041 Grenoble Cedex, France.

Corresponding author: Schwartz Stéphane

LIRIGM

Rue de la Piscine

BP 53

38041 Grenoble, Cedex

Email address: $\quad$ Stephane.Schwartz@ujf-grenoble.fr 


\begin{abstract}
New fission-track ages on zircon and apatite (ZFT and AFT) from the southwestern alpine paleo-accretionary wedge document a contrasting cooling history from east to west. In the eclogitic Monviso ophiolites, the ZFT ages are 19.6+/- 0.8 Ma and the AFT ages are 8.6+/1.7 Ma. In the HT-blueschist eastern Queyras, ZFT ages range from 27.0 +/- 1.5 Ma to 21.7 +/- 1.6 Ma and AFT ages from 14.2 +/- 2.0 to 9.4 +/- 1.1 Ma. In the LT-blueschist western Queyras, ZFT ages are between 94.7+/- 3.1 Ma and 63.1 +/- 2.9 Ma and AFT ages are between $22.2+/-1.6$ and $22.6+/-1.5$ Ma. The Chenaillet ophiolite yields ages of $118.1+/-$ 3.7 Ma on ZFT and of $67.9+/-8.5 \mathrm{Ma}$ on AFT. These new FT data combined with petrological and geochronological constraints record a diachronous exhumation in the paleoaccretionary wedge during subduction and collision.
\end{abstract}

Keywords: Southwestern Alps, fission-tracks, cooling rates, diachronous exhumation 


\section{Introduction}

Geochronological data combined with P-T estimates provide the information related to exhumation of high pressure low temperature (HP-LT) metamorphic rocks whether their metamorphism and exhumation were synchronous. In the Alpine belt, fission-track (FT) data are mostly obtained in central, eastern and northwestern domains (Hunziker et al., 1992; Seward and Mancktelow, 1994; Fügenschuh and Schmid, 2003; Malusà et al., 2005). There are very few age data from the Piedmont zone of the southwestern Alps. Furthermore, available FT data (Carpena and Caby, 1984) are not in accord with geochronological constraints based on other techniques (Duchêne et al., 1997a; Agard et al., 2002). The aim of this paper is to present new apatite and zircon FT data from meta-ophiolites and related oceanic meta-sediments in the blueschist and eclogite units from the Piedmont zone of the southwestern Alps (Fig. 1). These new data combined with petrological data constrain the exhumation processes in the western Alps.

\section{Geological setting}

The Piedmont zone of the southwestern Alps represents the juxtaposed domains during subduction and collision in late Cretaceous to Tertiary times (Tricart, 1984; Spalla et al., 1996). Three main ophiolite-bearing units are exposed from west to east (Fig. 1). At the top of the nappe pile, the Chenaillet massif represents an obducted portion of the Tethyan oceanic crust, escaping alpine metamorphism. This unit rests upon the Queyras "Schistes lustrés" complex composed of kilometric scale slices of meta-ophiolites embedded within Mesozoic meta-sedimentary rocks (Lemoine and Tricart, 1986). This unit shows increasing P-T conditions towards east, with LT-blueschist facies conditions in western Queyras up to the transitional condition between blueschist and eclogite facies in eastern Queyras (Caby, 1996; Agard et al., 2001; Schwartz et al., 2000). The blueschist units are structurally above the 
eclogitic Monviso ophiolites and the HP to UHP Dora Maira internal crystalline massif. In the Monviso massif, the meta-sedimentary component is very small $(<20$ vol\%) relative to voluminous oceanic lithosphere (Fig. 2). Eclogitic meta-gabbros occurred as boudins in a matrix of serpentinites or highly deformed meta-basalts. The calculated P-T conditions are heterogeneous among different boudins, suggesting that different fragments correspond to oceanic slab subducted to different depths (Blake et al., 1995; Schwartz et al., 2001).

\section{FT analysis and results}

\section{The Chenaillet unit}

Amphibolite to prehnite-pumpellyite facies conditions, representing the metamorphism on the ocean floor has been recognized by Mével et al. (1978). Fourteen grains of zircons in albitite dyke cross-cutting the amphibolitized meta-gabbros (Table 1) give a central age of $118+/-3.7$ Ma. The individual age dispersion is low (relative error of central age: $\mathrm{RE}<1 \%$ ), from 86.6 to $142.5 \mathrm{Ma}$, with a chi square test $\left(\mathrm{P} \chi^{2}\right)$ higher than $90 \%$ (Fig. 3a). For apatites, a central age of $67.9+/-8.5 \mathrm{Ma}$ was obtained on 9 grains. Despite their low uranium contents these apatites show a very low dispersion of individual ages $(\mathrm{RE}<1 \%)$ and a $\mathrm{P} \chi^{2}$ test higher than $85 \%$.

\section{The eclogitic Monviso ophiolites}

Fourty three grains of zircon and apatite were investigated from the Fe-Ti meta-gabbros of the Passo Gallarino unit (Table 1), which records the peak metamorphic condition of $450+/-$ $50^{\circ} \mathrm{C}$ and $13-15 \mathrm{kbar}$ (Schwartz et al., 2000). The data show low relative errors $(\mathrm{RE}<1 \%)$ and high score of the $\mathrm{P} \chi^{2}$ test (value $>99 \%$ ) and yield an age of $19.6+/-0.8 \mathrm{Ma}$ (Table 2 and Fig. 3d). In the case of apatites, 23 crystals have been dated with low uranium contents. However, all ages are in a range from 14.0 to $6.1 \mathrm{Ma}$, with a central age of $8.6+/-1.7 \mathrm{Ma}$ (RE $<1 \%$, (Fig. 2 and $3 \mathrm{~d}$ ) 


\section{The blueschist eastern Queyras domain}

The P-T conditions in the meta-gabbros (Table 1) have been estimated at $350-450{ }^{\circ} \mathrm{C}$ for a minimum pressure of 9 kbar (Caby, 1996; Schwartz, 2002), compatible with the development of chloritoïd-phengite assemblage in the metapelites implying $\mathrm{T}<450^{\circ} \mathrm{C}$ (Agard et al., 2001). The zircon central ages are 25.7+/- 1.2 Ma in the Casse de Peyroun area and $21.7+/-1.6 \mathrm{Ma}$ in the Rocca Nera area (Fig. 2). The apatite central ages are younger than the zircon central ages with ages of $14.2+/-2.0 \mathrm{Ma}$ in the Cirque de la Gavie area and of $9.4+/-1.1 \mathrm{Ma}$ in the Rocca Nera area (Fig. 2). All zircons have a small dispersion of the individual crystal ages, with the RE always lower than one per cent and a high $\mathrm{P} \chi^{2}$ test (Fig. 3 c). However, in the case of Rocca Nera, the $\mathrm{P} \chi^{2}$ is lower (value $>55 \%$ ) than in the other localities because of the low number of induced and spontaneous counted tracks (Table 2). The AFT results show a similar evolution, with a low dispersion of the individual crystal ages $(\mathrm{RE}<1 \%)$, but their central ages are always lower than the zircon central ages obtained in the same locality (Fig. $3 \mathrm{c}$ ).

\section{The blueschist western Queyras domain}

This domain corresponds to the westernmost part of the Piedmont zone (Fig. 2). P-T is estimated at 8-10 kbar for $300-350^{\circ} \mathrm{C}$ in the meta-gabbros (Caby, 1996; Schwartz, 2002), consistent with the development of carpholite in metapelites (Agard et al., 2001). Five ages have been obtained, two on apatites giving rise to homogeneous results around $22 \mathrm{Ma}$, and three on zircons with ages strongly varying between $63.1+/-2.9 \mathrm{Ma}$ (Cervières area) and 94.7 +/- 3.1 Ma (Rocher Blanc area) (Fig. 3b).

The ZFT ages show a very low dispersion for the individual crystal ages and a P $\chi^{2}$ test (Fig. 3b). In the sample from the Cervières area, ages were obtained only from two crystals of zircon, but the high density of induced and spontaneous tracks allows a central age of $63.1+/-$ 
2.9 Ma. These zircon ages are significantly older than the ages obtained by the same technique for the easternmost domains. Apatite ages have been obtained only for Rocher Blanc and Lago Nero areas. In both cases, the individual age dispersion is low $(\mathrm{RE}<1 \%)$ and the $\mathrm{P} \chi^{2}$ test is high (value $>90 \%$, Table 2). The central ages are compatible at about 22 Ma (Fig. 3b). In the case of the Lago Nero apatites, high uranium content allows to perform measurements of the confined track length (Fig. 3b). The track length distribution defines a symmetrical shape centered on $13.5+/-1.2 \mu \mathrm{m}$ compatible with a constant and progressive cooling of the sample through the partial retention zone (Dimitru, 1989).

\section{FT interpretation}

The FT data from both zircons and apatites show a pattern for a single age for each sample

(Fig. 3), suggesting that they record the time at which the rocks passed through their closure temperature. The closure temperature is a function of cooling rates (Dodson, 1981) and the FT closure temperature of zircons is $235-265^{\circ} \mathrm{C}$ (Zeitler et al, 1982) and $90-120^{\circ} \mathrm{C}$ for apatite (Hurford et al., 1991) in rocks with rapid cooling rate $\left(>10^{\circ} \mathrm{C} / \mathrm{Ma}\right)$.

The FT age data are summarized as follows:

- the Chenaillet massif was not affected by alpine metamorphism. Even the low-temperature metamorphism (greenschist facies and prehnite-pumpellyite facies) must be older than $65 \mathrm{Ma}$, suggesting that the ophiolite was obducted before $65 \mathrm{Ma}$;

- Monviso and eastern Queyras show progressively older ages towards the west and tectonic upper levels (Fig.4). The eclogitic Monviso ophiolites cooled below $110^{\circ} \mathrm{C}$ only $9 \mathrm{Ma}$ ago. Combining zircon and apatite ages yields a mean cooling rate of 10 to $12^{\circ} \mathrm{C} / \mathrm{Ma}$ (Fig.4);

- in western Queyras, the AFT ages are similar, around $22 \mathrm{Ma}$, whereas zircon ages vary widely. The wide variation in zircon ages is explained by low temperature metamorphic condition $\left(\mathrm{T}<350^{\circ} \mathrm{C}\right)$, which is close to the fission-track annealing temperature of zircon 
$\left(330^{\circ} \mathrm{C}\right.$; Yamada et al., 1995; Tagami et al., 1996; Tagami and Shimada, 1996). Thus these ages have no geological significance. The extrapolation of the trend obtained for the ZFT ages towards the west suggests that the western Queyras probably cooled below $240^{\circ} \mathrm{C}$ between 39 and $31 \mathrm{Ma}$ (Fig. 4);

- the cooling histories of different ophiolite-bearing metamorphic units are diachronous. The easternmost eclogitic units cooled later and thus exhumed later than the westernmost blueschist units.

\section{Alpine temperature-time paths}

The combination of our results with the available chronological constraints for the internal zones of the southwestern Alps (see Table 3) allows T-t paths to be constructed for both eclogitic and blueschist facies units (Fig.5).

\section{The blueschist Queyras units}

In eastern Queyras, Ar-Ar ages of phengites are interpreted as the beginning of cooling while in western Queyras, Ar-Ar ages correspond to the crystallization ages of phengites, synchronous with the HP paragenesis (Table 3). The T-t paths show a diachroneity in the cooling history of a minimum of $5 \mathrm{Ma}$ (Fig. 5). The eastern Queyras is first metamorphosed and partly cooled while western Queyras did not yet reached its thermal metamorphic peak condition. Since $43 \mathrm{Ma}$ (at $\mathrm{T} \sim 300^{\circ} \mathrm{C}$ ), cooling trends reversed and the western unit cooled before eastern unit, until the exhumation ended. Cooling rates varied with time, but remain low between 4 and $11^{\circ} \mathrm{C} / \mathrm{Ma}$. The similar cooling paths for western and eastern Queyras suggest that they were exhumed by the similar process but not at the same time.

\section{The eclogitic Monviso domain}


The Monviso is characterized by high cooling rates $\left(>35^{\circ} \mathrm{C} / \mathrm{Ma}\right)$ in the initial period, but the cooling rate decreased to $4.9^{\circ} \mathrm{C} / \mathrm{Ma}$ between 400 and $300^{\circ} \mathrm{C}$ and ca. $12^{\circ} \mathrm{C} / \mathrm{Ma}$ below $250^{\circ} \mathrm{C}$ (Fig. 5). Immediately after the pressure peak, eclogites were exhumed rapidly up to a depth of about $20 \mathrm{~km}$. In a second stage, the cooling rate decreases. During this final exhumation, the shape of the temperature-time path for the Monviso domain is similar to the Queyras units. However, the Monviso eclogites were cooled and thus exhumed latter than the blueschist facies rocks.

\section{Tectonic consequences and discussion}

Arguments for a major tectonic contact in the Piedmont Schistes lustrés

The Schistes lustrés and Monviso unit are separated by a ductile normal fault (Ballèvre et al., 1990). Our chronological data confirm that this must be a major tectonic contact inside the Piedmont zone. The proposed interpretation is supported by different lithologies, metamorphic conditions and cooling ages between the two units. The blueschist facies domain is mainly composed of meta-sediments with small and isolated ophiolitic bodies whereas the eclogitic domain corresponds to slices of oceanic lithosphere with minor metasediments. More generally, our results suggest that the alpine HP-LT metamorphic zoning cannot be regarded as progressive change in the metamorphic grade from west to east. Instead, each metamorphic zone likely corresponds to a juxtaposed tectonic unit with its own cooling history.

Arguments for a Paleocene to Eocene intra-oceanic subduction zone.

Our data are consistent with an intra-oceanic subduction zone for the Alpine Piedmont zone

(Fig. 6). It is difficult to estimate the location of Chenaillet ophiolite in the Piedmont oceanic domain, but it remained in the upper tectonic position. Emplacement of the Chenaillet unit 
onto the European margin could have occurred between upper Cretaceous and Eocene. During the Paleocene or Eocene, the Piedmont zone was metamorphosed under blueschist facies conditions in an accretionnary wedge, while the eclogitized meta-ophiolites represent pieces of the subducted oceanic lithosphere. During active subduction, pieces of eclogites are exhumed in a serpentinized subduction channel (Hermann et al., 2001; Schwartz et al., 2001).

\section{Continental subduction and decrease of the exhumation rates}

The UHP metamorphism in the Dora-Maira massif (Fig. 5) occurred at about 31-35 Ma (Duchêne et al., 1997b; Gebauer et al., 1997; Cliff et al., 1998). Considering this massif as remnant of the European continental margin, the continental subduction started prior Oligocene time. A low convergence rate, of about $6-8 \mathrm{~mm} \cdot \mathrm{yr}^{-1}$, between Africa and Europe from Late Cretaceous to Eocene (Jolivet and Facenna, 2000; Schettino and Scotese, 2002) suggests a minimum of $17 \mathrm{Ma}$ for the Dora Maira massif to reach the depth of $120 \mathrm{~km}$ recorded by the UHP metamorphism. This implies that the continental subduction probably initiated before 45-50 Ma in the southwestern Alps, i.e. at the time of the HP metamorphism in the Monviso ophiolites. Thus we propose that the onset of exhumation of the Piedmont zone is broadly contemporaneous with the initial continental subduction of the Dora Maira massif. The increased exhumation rate of the Queyras Schistes lustrés and the Monviso after $30 \mathrm{Ma}$ is synchronous with the onset of exhumation of the Dora Maira massif (Fig. 5) and the initiation of the intracrustal Pennic frontal thrust, which mark the transition from subduction to collision dynamics.

\section{Conclusions}

Coupled FT dating on zircons and apatites from meta-ophiolites of the Piedmont zone documents diachronous cooling histories for four different tectono-metamorphic units. 
1- the Chenaillet unit was cooled below $110^{\circ} \mathrm{C}$ before $65 \mathrm{Ma}$;

2- The exhumation of eclogite and blueschist facies rocks is diachronous, which confirms the existence of a major tectonic contact inside the Piedmont zone between the two units.

Three tectonic domains likely represent remnants of three different structural levels of the same paleo-subduction zone. (i) The highest structural level corresponds to the Chenaillet unit as obducted upon the European margin. (ii) The blueschist Queyras units (eastern and western Queyras) corresponds to deformed accretionary wedge, while (iii) the Monviso eclogitic units the subducted oceanic slab and exhumed in a serpentinite channel.

\section{Acknowledgments}

The authors are grateful to K. Hattori, D. Seward and L. Jolivet for their helpful comments. We thank G. Poupeau for fission-tracks laboratory facilities. This work was supported by the CNRS-BRGM program "Geo-France 3D - Alpes". 


\section{References}

Agard, P., Jolivet, L., Goffé, B., 2001. Tectonometamorphic evolution of the Schistes lustrés complex : implications for the exhumation of HP and UHP rocks in the western Alps. Bulletin de la société géologique de France, 5, 604-617.

Agard, P., Monié, P., Jolivet, L. and Goffé, B., 2002. Exhumation of the Schistes Lustrés complex: in situ laser probe ${ }^{40} \mathrm{Ar} /{ }^{39} \mathrm{Ar}$ constraints and applications for western Alps. Journal of Metamorphic Geology, 20, 599-618.

Ballèvre, M., Lagabrielle, Y. and Merle, O., 1990. Tertiary ductile normal faulting as a consequence of lithospheric stacking in the Western Alps. Mémoires de la Société Géologique de France, 156, 227-236.

Blake, M.C., Moore, D.E. and Jayko, A.S., 1995. The role of the serpentinite melange in the unroofing of UHP metamorphic rocks: an example from western Alps of Italy, in: Coleman R.G. and Wang X. (Eds), Ultrahigh pressure metamorphism, Cambridge University Press, 182-205.

Caby, R., 1996. Low-angle extrusion of high-pressure rocks and the balance between outward and inward displacements of middle penninic units in the western Alps. Eclogae geologicae Helvetiae, 89/1, 229-267.

Capena J. and Caby R., 1984. Fission-track evidence for late Triassic oceanic crust in French occidental Alps. Geology, 12, 108-111. 
Cliff, R.A., Barnicoat, A.C. and Inger, S., 1998. Early Tertiary eclogite facies metamorphism in the Monviso Ophiolite. Journal of Metamorphic Geology, 16, 447-455.

Dodson, M.H., 1981. Thermochronometry. Nature, 293, 606-607.

Duchêne, S., Lardeaux, J.M. and Albarède, F., 1997a. Exhumation of eclogites: Insights from retrograde depth-time path analysis. Tectonophysics, 280, 125-140.

Duchêne, S., Blichert-Toft, Luais, B., Télouk, P., Lardeaux, J.M. and Albarède, F., 1997b. The Lu-Hf dating of the garnets and the ages of the Alpine high-pressure metamorphism. Nature, 387, 586-589.

Dumitru, T.A., 1989. Constraints on uplift in the franciscan subduction complex from apatite fission-track analysis. Tectonics, 8, 197-220.

Fügenschuh, B. and Schmid, S.M., 2003. Late stages of deformation and exhumation of an orogen constrained by fission-track data: A case study in Western Alps. GSA Bulletin, 115, $1425-1440$.

Galbraith, R.F., 1990. The radial plot: graphical assessment of spread in ages. Nuclear tracks, 17, 207-214.

Galbraith, R.F., 1992. Statistical models for mixed ages. Abstracts with programs, 7th International Workshop on Fission-track Thermochronology, University of Pennsylvania, July 1992,7 
Gebauer, D., Schertl, H.P., Brix, M. and Schreyer, W., 1997. 35Ma old ultrahigh-pressure metamorphism and evidence for very rapid exhumation in the Dora Maira massif, Western Alps. Lithos, 5-24.

Gleadow, A.J.W., 1981. Fission-track dating methods: what are the real alternatives? Nuclear Tracks, 5, 3-14.

Gleadow, A.J.W., Hurford, A. and Quaife, D.R., 1976. Fission-track dating of zirconimproved etching techniques. Earth and Planetary Science Letters, 33, 273-276.

Hermann, J., Müntener, O. and Scambelluri, M., 2001. The importance of serpentinite mylonites for subduction and exhumation of oceanic crust. Tectonophysics, 327, 225-238.

Hunziker, J.C., Desmons, J. and Hurford, A., 1992. Thirty-two years of geochronological work in the Central and Western Alps: a review on seven maps. Mémoires de Géologie de Lausanne, 13, 59p.

Hurford, A. and Green, P.F., 1983. The zeta age calibration of fission-track dating. Isotope Geoscience, 1, 285-317.

Hurford, A., 1990. International Union of Geophysical Sciences subcommission on geochronology recommandation for standardization of fission-track dating calibration and data reporting. Nuclear Tracks, 2, 233-236. 
Hurford, A., Stockhert, B. and Hunziker, J.C., 1991. Constraints on the late thermotectonic evolution of the Western Alps: evidence for episodic rapid uplift. Tectonics, 10, 758-769.

Jolivet, L. and Faccenna, C., 2000. Mediterranean extension and the Africa-Eurasia collision. Tectonics, 19 (6), 1095-1106.

Lemoine, M. and Tricart, P., 1986. Les Schistes lustrés des Alpes occidentales: approche stratigraphique, structurale et sédimentologique. Eclogae geologicae Helvetiae, 79, 271-294.

Malusà, G., Polino, R., Zattin, M., Bigazzi, G., Martin, S. and Piana, F., 2005. Miocene to Present differential eshumation in Western Alps: Insights from fission track thermochronology. Tectonics, 24, TC3004, 1-23.

Monié, P. and Philippot, P., 1989. Mise en évidence de l'âge Eocène moyen du métamorphisme de haute-pression de la nappe ophiolitique du Mont Viso (Alpes occidentales) par la méthode 39A/40Ar. Comptes Rendus de l'Académie des Sciences, 309, 245-251.

Mével, C., Caby, R. and Kienast, J.R., 1978. Amphibolite facies conditions in oceanic crust: example of amphibolitized flaser gabbros and amphibolites from the Chenaillet ophiolite massif (Hautes Alpes, France). Earth \& Planetary Science Letters, 39, 98-108.

Schettino, A. and Scotese, C., 2002. Global kinematic constraints to the tectonic history of the Mediterranean region and surrounding areas during the Jurassic to the Cretaceous. Journal of Virtual Explorer, 8, 145-160. 
Schwartz, S., Lardeaux, J.M., Guillot, S. and Tricart, P., 2000. Diversité du métamorphisme éclogitique dans le massif ophiolitique du Monviso (Alpes Occidentales, Italie). Geodinamica Acta, 13, 169-188.

Schwartz, S., 2002. La zone Piémontaise des Alpes occidentales: un paléo-complexe de subduction. Arguments métamorphiques, géochronologiques et structuraux. Documents BRGM, Orléans, 302, 313p.

Schwartz S., Allemand P. and Guillot S., 2001. Numerical model of the effect of serpentinites on the exhumation of eclogitic rocks: insights from the Monviso ophiolitic massif (western Alps). Tectonophysics, 342, 193-206.

Seward, D. and Mancktelow, N. S., 1994. Neogene kinematics of central and western Alps: evidence from fission-track dating. Geology, 22, 803-806.

Spalla, M.I., Lardeaux, J.M., Dal Piaz, G.V., Gosso, G. and Messiga, B., 1996. Tectonic significance of alpine eclogites. Journal of Geodynamics, 21, 257-285.

Tagami, T., Carter, A. and Hurford, A.J., 1996. Natural long-term annealing of the zircon fission-track system in Vienna basin deep borehole samples: constraints upon the partial annealing zone and closure temperature. Chemical Geology, 130, 147-157.

Tagami, T. and Shimada, C., 1996. Natural long-term annealing of the zircon fission-track system around a granitic pluton. Journal of Geophysical Research, 101, 8245-8255. 
Tricart, P., 1984. From passive Margin to continental collision: a tectonic scenario for the Western Alps. American Journal of Science, 284, 97-120.

Tricart, P., Schwartz, S., Sue, C. and Lardeaux, J.M. Evidence for synextensional tilting and doming during during final exhumation from analysis multistage faults (Queyras, Schistes lustrés, Western Alps), Journal of Structural Geology 26, 1633-1645, 2004.

Yamada, R., Tagami, T., Nishimura, S. and Ito, H., 1995. Annealing kinematics of fissiontracks in Zircon: an experimental study. Chemical Geology, 122, 249-258

Zietler, P.K., Naeser, C.W., Johnson, N.M. and Tahirkheli, R.A.K., 1982. Fission-track evidence for the Quaternary uplift of the Nanga Parbat region, Pakistan. Nature, 298, 255257. 


\section{Figure captions.}

Fig. 1 - Simplified tectonic map of the western Alps, with Argentera-Mercantour (AM), Pelvoux (P), Mont Blanc (MB), Sesia (SE), Dent Blanche (DB), Dora-Maira (DM), GranParadiso (GP), Monte-Rosa (MR); a-Schistes lustrés; b-ophiolites with Chenaillet massif (CHE).

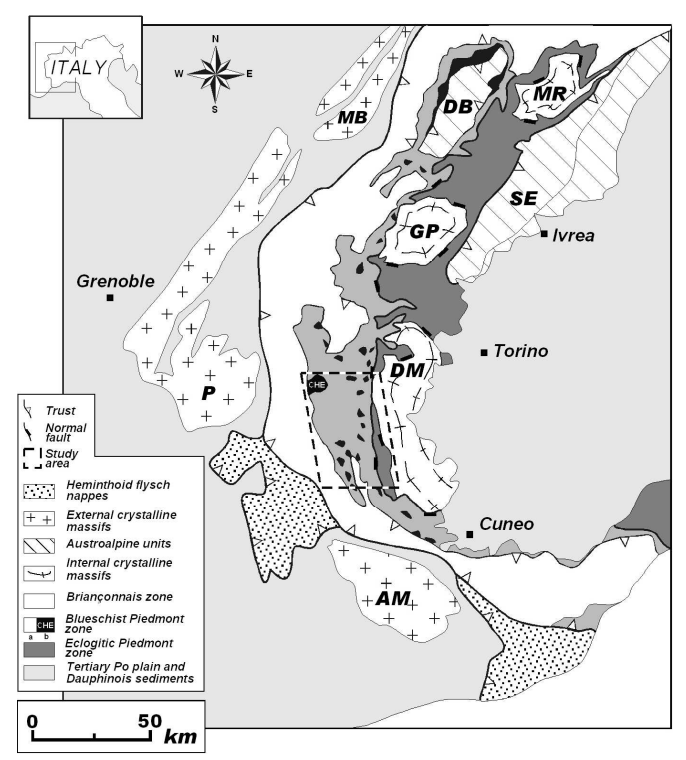

Fig. 2 - The new thermochronological data. 1-Chenaillet obducted ophiolite; 2-Briançonnais zone; 3-Blueschist western Queyras domain; 4-Blueschist eastern Queyras domain; 5Eclogitic Monviso domain; 6-Acceglio zone; 7-Dora Maira crystalline massif; 8-Scattered blueschist ophiolites within the schistes lustrés complex. 9-Three main directions of lineaments, respectively N35E strike-slip faults and N60E and N160E normal faults (after Tricart et al., 2004). A-A' line locates the cross section in figure 4. 


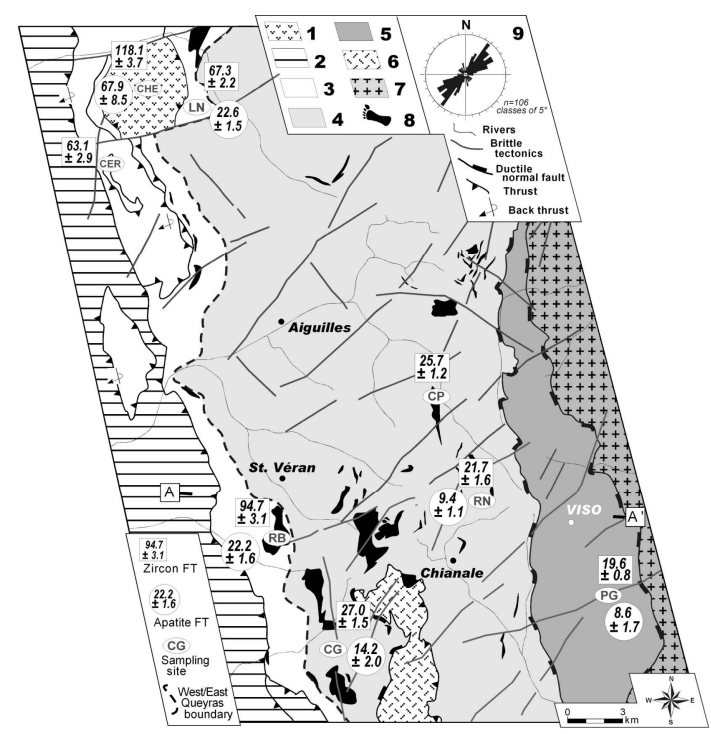

Fig. 3 - Radial plots of apatite and zircon ages for the different metamorphic domains of the Piedmont zone. The count data are presented using the radial plot of Galbraith (1990), corresponding to a graphical device for comparing crystals of differing ages and differing precisions. The position of the $x$ scale records the uncertainty of individual grain estimates (dependant on the number of counted tracks), whilst each point has the same standard error in the $y$ direction (indicated by the vertical +2 to -2 bar). The plot also includes a circular age scale such that the age of any crystal may be determined by extrapolating a line from the origin through the crystal's $x, y$ coordinates to intercept the age scale. For the Lago Nero unit (LN) the apatite track-length measurements are presented. These data are displayed as a histogram with individual measurements grouped in $1 \mu \mathrm{m}$ bins. The number of tracks in each bin is represented on the $y$ axis.




Fig. 4 - Cooling rates for the different tectono-metamorphic units presented on a cross section of the study area (A-A' transect in figure 2). The distribution of the cooling ages supports diachronous histories for the different units. In western Queyras, the non significant ZFT ages are related to the too low temperature conditions recorded during Alpine metamorphism (under $350^{\circ} \mathrm{C}$ ). For the western Queyras the extrapolation of the trend obtained in the eastern part probably suggests that the western Queyras cooled below $240^{\circ} \mathrm{C}$ between 39 and $31 \mathrm{Ma}$. The ZFT and AFT ages are plotted in age / altitude diagram (we do not report ZFT data from the Chenaillet and the western Queyras). There is no clear correlation between the calculated ages and the altitudes, which suggests that the Piedmont zone was not exhumed as a single crustal unit. This is in agreement with the widespread occurrence of a post-metamorphic extensional brittle tectonics. As a consequence the Piedmont zone is composed of different blocks bounded by brittle faults.

Fig. 5 - Temperature-time paths for Monviso, western and eastern Queyras established by the compilation of geochronological data available in the Piedmont zone of the southwestern Alps. All radiometric data with references are presented in Table 3. Cooling rates are also indicated for each unit. These temperature-time paths support the diachronism of exhumation between blueschist and eclogitic units of the Piedmont zone.

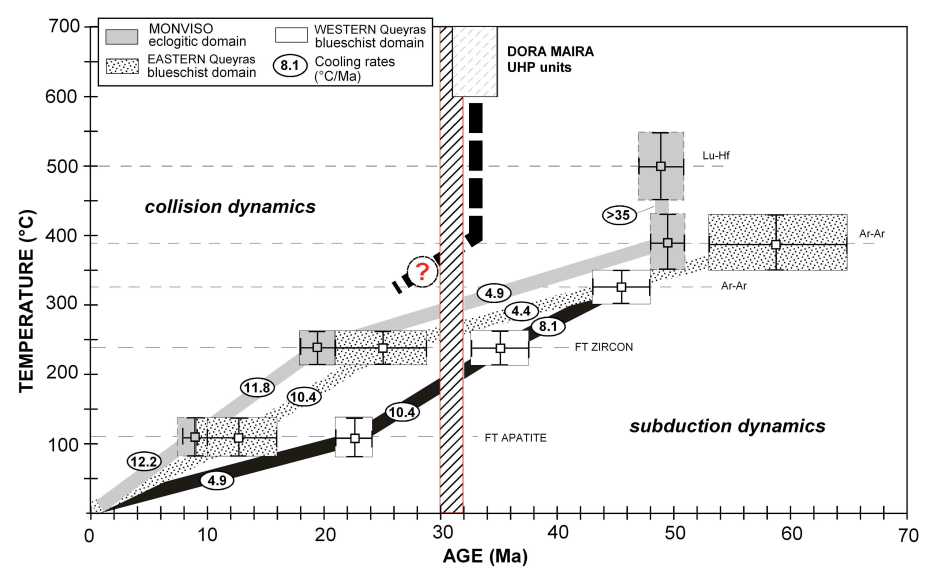


Fig. 6 - Tectonic sketch of the Piedmont zone during the Eocene. The different metamorphic domains that presently outcroup in the Piedmont zone "sample" different levels of a paleosubduction zone.

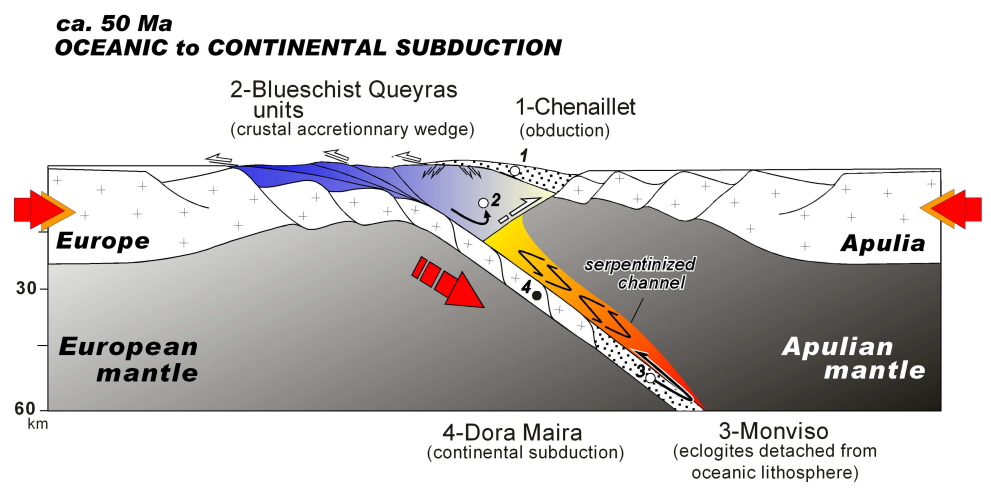

Tab. 1 - Sample locations and petrological descriptions of rocks used for ZFT and AFT investigations. Elevation is in meters above sea level and geographic coordinates are latitude and longitude.

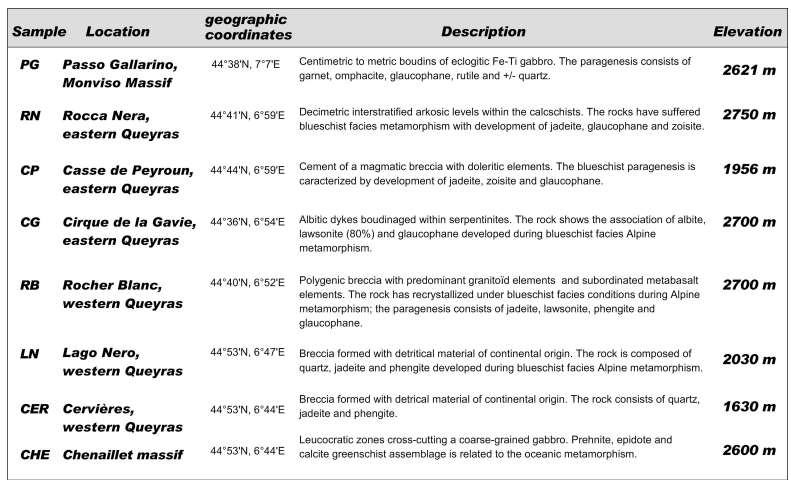

Tab. 2 - Global fission-track data measured for the Piedmont zone of the southwestern Alps. Zircons and apatites were separated using conventional rock-crushing, heavy liquids, Frantz magnetic separator and hand picking. Polishing and etching procedures were those recommended by Hurford (1990). All samples were analysed by the external detector method (Gleadow, 1981) which allowed the uranium concentration and age for individual crystals to be determined. Prior to irradiation, all zircons were etched using the $\mathrm{KOH}-\mathrm{NaOH}$ eutectic at $220^{\circ} \mathrm{C}$ during 15 hours (Gleadow et al., 1976) and all apatites were etched with $1 \mathrm{~N}^{-N^{2}}{ }_{3}$ at $20^{\circ} \mathrm{C}$ during 50 seconds. Samples were irradiated at the Orphée reactor of the Centre d'Etudes 
Nucléaires of Saclay, France. Neutron fluences were monitored using uranium glass dosimeters (CN-1 for zircon irradiations and $\mathrm{CN}-5$ for apatite irradiations). Ages were calculated using the zeta calibration approach, whereby a proportionality constant zeta is evaluated by multiple analysis of mineral standards of known age (Hurford and Green, 1983). Zeta values used in this study have been determined from repeated measurements of standard zircons from the Fish Canyon Tuff (USA) and standard apatites from the Durango deposit (Mexico) and the Fish Canyon Tuff (USA). Track densities $(\rho)\left(\times 10^{5}\right.$ tracks $\left.\mathrm{cm}^{-2}\right)$, number of tracks counted (n) shown in brackets. All analyses by external detector method use 0.5 as $4 \pi / 2 \pi$ geometry correction factor. Apatite ages calculated using dosimeter glass CN-5; zircon ages calculated using dosimeter glass CN-1 (Hurford and Green, 1983). $\mathrm{P} \chi^{2}$ is the probability of obtaining $\chi^{2}$ value for $v$ degrees of freedom (where $v=$ number of crystals -1 ). RE is the relative error of central age. The ages correspond to the central ages following Galbraith (1992). These central ages are modal ages, weighted to account for the differing precision of the individual crystal age. Two uncertainties are related to the central age: the $+/$ - indicates the analytical precision, while an estimate of the age dispersion (or the spread of the individual crystal data) is given by the relative standard error of the central age (RE). In our results the dispersion is always low $(<10 \%)$ leading to the recognition of a single age population. All uncertainties are quoted at $1 \sigma$ level.

\begin{tabular}{|c|c|c|c|c|c|c|c|c|c|c|c|c|}
\hline \multirow[t]{2}{*}{ Sample } & \multirow[t]{2}{*}{ Mineral } & \multirow{2}{*}{$\begin{array}{l}\text { Number } \\
\text { of } \\
\text { Crystals }\end{array}$} & \multicolumn{2}{|c|}{ Spontaneous } & \multicolumn{2}{|c|}{ induced } & \multirow{2}{*}{$\begin{array}{l}\mathrm{P} \chi^{2} \\
\%\end{array}$} & \multirow{2}{*}{$\begin{array}{l}\mathrm{RE} \\
\%\end{array}$} & \multicolumn{2}{|c|}{\begin{tabular}{|l|l} 
Dosimeter \\
\end{tabular}} & \multirow{2}{*}{$\begin{array}{c}\text { Zeta }( \pm \sigma) \\
\zeta\end{array}$} & \multirow{2}{*}{$\begin{array}{l}\text { Age } \pm 1 \sigma \\
\mathrm{Ma}\end{array}$} \\
\hline & & & $\rho_{\mathrm{s}}$ & $\left(\mathrm{N} s_{\mathrm{s}}\right)$ & $\rho_{\mathrm{i}}$ & $\left(\mathrm{Ni}_{\mathrm{i}}\right.$ & & & & $(\mathrm{Nd})$ & & \\
\hline \multicolumn{13}{|c|}{ Eclogitic domain (Monviso) } \\
\hline PG & $\begin{array}{l}\text { apatite } \\
\text { zircon }\end{array}$ & $\begin{array}{l}23 \\
43 \\
\end{array}$ & $\begin{array}{l}0.049 \\
2.43\end{array}$ & $\begin{array}{r}(28) \\
(764) \\
\end{array}$ & $\begin{array}{l}1.59 \\
2.25 \\
\end{array}$ & $\begin{array}{l}(914) \\
(709)\end{array}$ & $\begin{array}{l}>99 \\
>99 \\
\end{array}$ & $\begin{array}{l}<1 \\
<1 \\
<\end{array}$ & $\begin{array}{l}19.39 \\
2.90\end{array}$ & $\begin{array}{l}(15899) \\
(10734)\end{array}$ & $\begin{array}{l}289 \pm 13 \\
125 \pm 3\end{array}$ & \begin{tabular}{|l}
$8.6 \pm 1.7$ \\
$19.6 \pm 0.8$
\end{tabular} \\
\hline \multicolumn{13}{|c|}{$\begin{array}{l}\text { Blueschist domain } \\
\text { (eastern Queyras) }\end{array}$} \\
\hline RN & $\begin{array}{l}\text { apatite } \\
\text { zircon }\end{array}$ & $\begin{array}{l}14 \\
3\end{array}$ & $\begin{array}{l}0.810 \\
39.40\end{array}$ & $\begin{array}{l}(94) \\
(164)\end{array}$ & $\begin{array}{l}24.03 \\
23.30\end{array}$ & $\begin{array}{r}(2786) \\
(97)\end{array}$ & $\begin{array}{c}>99 \\
56\end{array}$ & $\begin{array}{l}<1 \\
<1\end{array}$ & $\begin{array}{l}19.39 \\
2.05\end{array}$ & $\begin{array}{l}(15899) \\
(10854)\end{array}$ & $\begin{array}{l}289 \pm 13 \\
125 \pm 3\end{array}$ & $\begin{array}{l}9.4 \pm 1.1 \\
21.7 \pm 1.6\end{array}$ \\
\hline CP & zircon & 15 & 5.27 & (489) & 2.64 & (245) & $>99$ & $<1$ & 2.05 & (10854) & $125 \pm 3$ & $25.7 \pm 1.2$ \\
\hline cG & $\begin{array}{l}\text { apatite } \\
\text { zircon }\end{array}$ & $\begin{array}{l}31 \\
19 \\
\end{array}$ & \begin{tabular}{|l|l}
0.255 \\
1.80
\end{tabular} & $\begin{array}{r}(57) \\
(285)\end{array}$ & $\begin{array}{l}5.01 \\
1.21 \\
\end{array}$ & $\begin{array}{r}(1120) \\
(192) \\
\end{array}$ & $\begin{array}{l}>99 \\
>99 \\
\end{array}$ & $\begin{array}{l}<1 \\
<1\end{array}$ & $\begin{array}{l}19.39 \\
2.90\end{array}$ & $\begin{array}{l}(15899) \\
(10734)\end{array}$ & $\begin{array}{l}289 \pm 13 \\
125 \pm 3\end{array}$ & $\begin{array}{l}14.2+2.0 \\
27.0 \pm 1.5 \\
\end{array}$ \\
\hline \multicolumn{13}{|c|}{$\begin{array}{l}\text { Blueschist domain } \\
\text { (western Queyras) }\end{array}$} \\
\hline$R B$ & $\begin{array}{l}\text { apatite } \\
\text { zircon }\end{array}$ & $\begin{array}{l}26 \\
12\end{array}$ & \begin{tabular}{l|}
1.32 \\
73.00
\end{tabular} & $\begin{array}{r}(263) \\
(2532)\end{array}$ & $\begin{array}{l}2.87 \\
9.86\end{array}$ & $\begin{array}{l}(574) \\
(342)\end{array}$ & $\begin{array}{r}>99 \\
95\end{array}$ & $\begin{array}{l}<1 \\
<1\end{array}$ & $\begin{array}{l}3.37 \\
2.05\end{array}$ & $\begin{array}{r}(9090) \\
(10854)\end{array}$ & $\begin{array}{l}289 \pm 13 \\
125 \pm 3\end{array}$ & $\begin{array}{l}22.2 \pm 1.6 \\
94.7 \pm 3.1\end{array}$ \\
\hline $\mathbf{L N}$ & $\begin{array}{l}\text { apatite } \\
\text { zircon }\end{array}$ & $\begin{array}{l}14 \\
11\end{array}$ & \begin{tabular}{|l|}
4.62 \\
72.50
\end{tabular} & $\begin{array}{r}(374) \\
(2425)\end{array}$ & $\begin{array}{l}9.92 \\
13.80\end{array}$ & $\begin{array}{l}(803) \\
(462)\end{array}$ & $\begin{array}{l}>99 \\
>99\end{array}$ & $\begin{array}{l}<1 \\
<1\end{array}$ & $\begin{array}{l}3.37 \\
2.05\end{array}$ & $\begin{array}{r}(9090) \\
(10854)\end{array}$ & $\begin{array}{l}289 \pm 13 \\
125 \pm 3\end{array}$ & \begin{tabular}{|l}
$22.6 \pm 1.5$ \\
$67.3 \pm 2.2$
\end{tabular} \\
\hline CER & zircon & 2 & 165.00 & $(423)$ & 33.60 & (86) & 70 & $<1$ & 2.05 & (10854) & $125 \pm 3$ & $63.1 \pm 2.9$ \\
\hline \multicolumn{13}{|c|}{\begin{tabular}{|c|} 
Without Alpine metamorphism \\
(Chenaillet massif)
\end{tabular}} \\
\hline CHE & $\begin{array}{l}\text { apatite } \\
\text { zircon }\end{array}$ & $\begin{array}{l}9 \\
14\end{array}$ & $\begin{array}{l}0.958 \\
80.50\end{array}$ & $\begin{array}{r}(57) \\
(3385)\end{array}$ & $\begin{array}{l}2.00 \\
8.70\end{array}$ & $\begin{array}{l}(119) \\
(366)\end{array}$ & $\begin{array}{l}87 \\
92\end{array}$ & $\begin{array}{l}<1 \\
<1\end{array}$ & $\mid \begin{array}{l}9.88 \\
2.05\end{array}$ & $\begin{array}{l}(10454) \\
(10854)\end{array}$ & $\begin{array}{l}289 \pm 13 \\
125 \pm 3\end{array}$ & \begin{tabular}{|c|}
$67.9 \pm 8.5$ \\
$118.1 \pm 3.7$
\end{tabular} \\
\hline
\end{tabular}

